
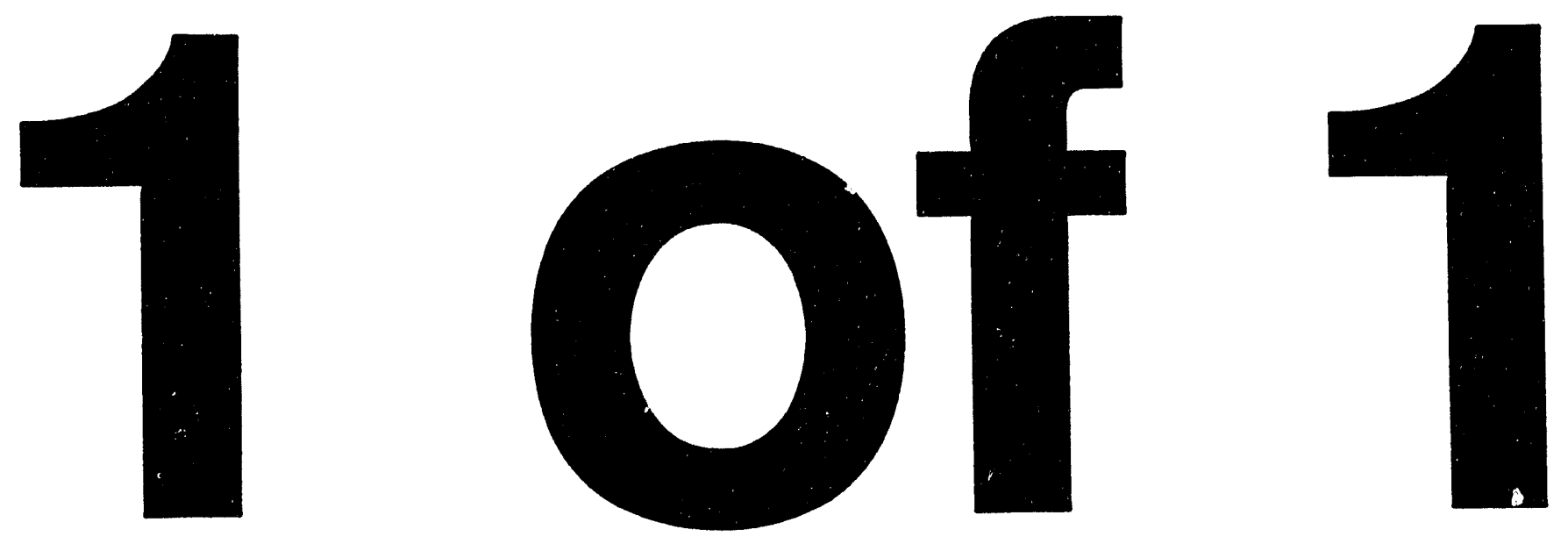


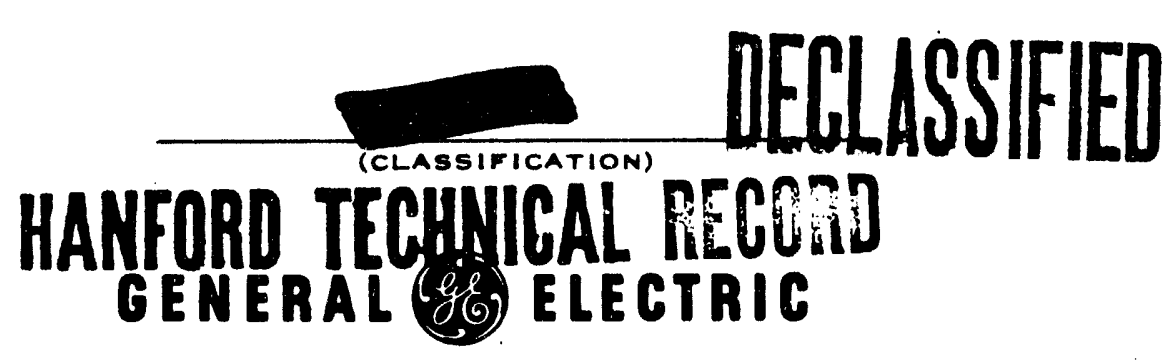

HANFORD ATOMIC PRODUCTS OPERATION - RICHLAND, WASHINGTON
DOCUMENT NO.

HW -69912

BERIES AND COPY NO.

A 20

June 12,1961

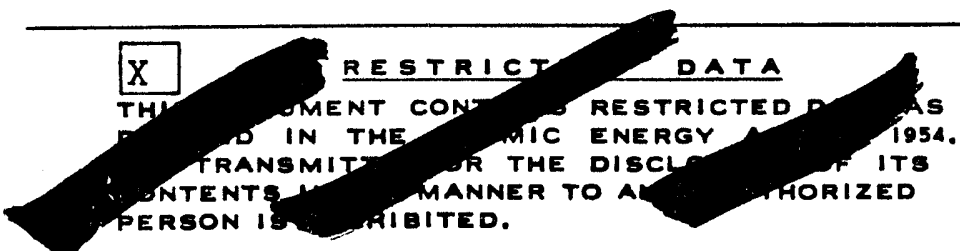

PERBON I

OTHER OFFICIAL CLASSIFIED INFORMATION

THIS MATERIAL CONTAINS INFORMATION AFFECTING THE NATIONAL DEFENSE OF THE UNITED STATES WITHIN THE MEANING OF THE ESPIONAGE LAWS, TITLE 18, U. S.C., SECS. 793 AND 794, THE TRANSMISSION OR REVELATION OF WHICH IN ANY MANNER TO AN UNAUTHORIZED PERSON IS PROHIBITED BY LAW.

THIS DOCUMENT TO IT. WHEN N GUAREED CLASSI

TH. ILES, IT I
ECT AND FROM
SIDENCE IS PK TO SIGN IN THE BPACE PROVIDED BELOW.

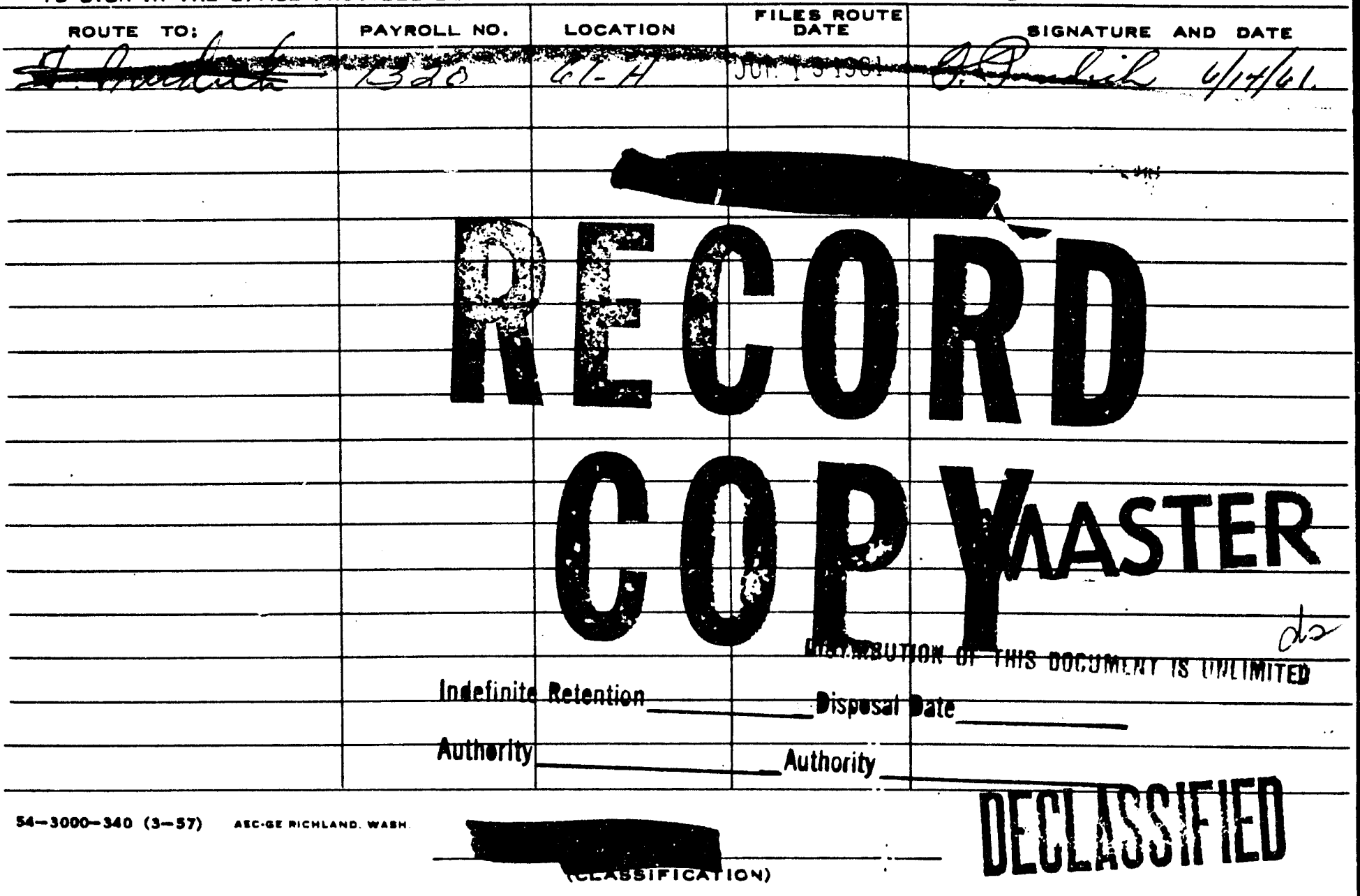

Product Quality and an Interim Goal Exposure Plan

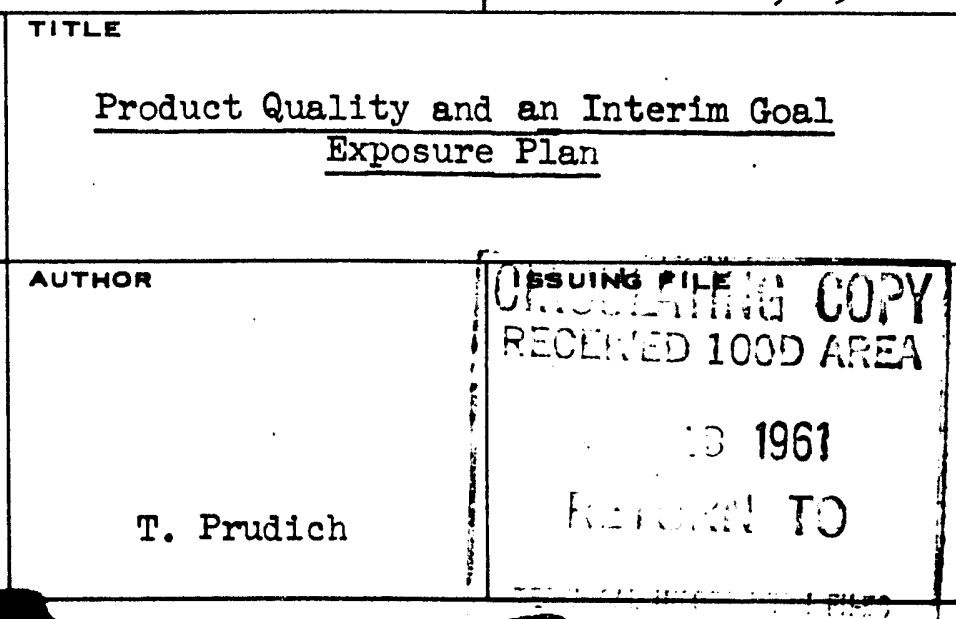

WAERE AN UNAUTHORIzER- MAY haVe ACceśs WHERE AN UNAUTHORIZER MAY HAVE ACCESS NO UNTIL YOU HN INED A SIONED RECEIP APRO CONTENTS WITHIN THE TONTENTS WITHIN TH
TAL TO, AND STORAOY C " "NE REQUIRED, AD. IF ADDITIONAL TORA ARE REQUE STED
AREQUIRED, 
This ducument consists of 2 pages. Copy No. 20 of 26 copies.

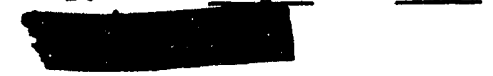

Distribution:

1. J.T. Baker

2. J. W. Baker

3. R. J. Bursey

4. R. G. Clough

5. W. J. Ferguson

6. D. S. Lewis

7. S. L. Nelson

8. A. P. Vinther

9. R. S. Bell

10. R. W. Bown

11. V. R. Chapman

12. E. J. Filip

13. G. C. Fullmer
14. S. M. Graves

15. O. H. Greager

16. C. N. Gross

17. A. R. Maguire

18. G. F. Owsley

19. C. A. Priode

$>20$. T. Frualeh

2I. R. W. Reid

22. W. D. Ri nhmond

23. 0. C. Schroeder

24. H. G. Spencer

25. 300 File

26. Record Copy
J. T. Baker

J. W. Baker

R. J. Bursey

R. G. Clough

W. J. Ferguson

D. S. Lewis

S. L. Nelson

A. P. Vinther
Chentication Conoulod and Changed To

June 12,1961

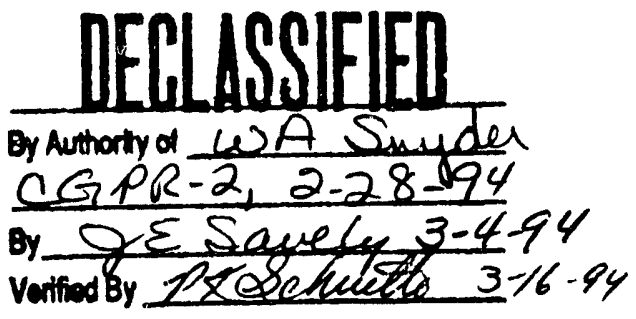

\section{PRODUCT QUALITY AND AN INTERIM GOAL EXPOSURE PLAN}

There has been considerable discussion recently concerning a plutonium specification which restricts the acceptable range of Pu-240 in uranium discharged. our problem is to control Pu-240 on a continuing basis so that material flowing from the reactors to CPD will meet the specification after limited blending. Storage basin capacity and good operating practice preclude additional holding time to facllitate extensive blending. Some blending normally occurs in CPD dissolvers and further blending will be accomplished by careful charging of Redox and Purex with subsequent blending of their product streams. However, it is not feasible to maintain close control over this blending through frequent 1sotopic analysis of these streams. One of the most effective controls, at least initially, must be the discharging of a falrly unfform product with respect to Pu-240 content. As experience is gained we hope to be able to incorporate more flexibility.
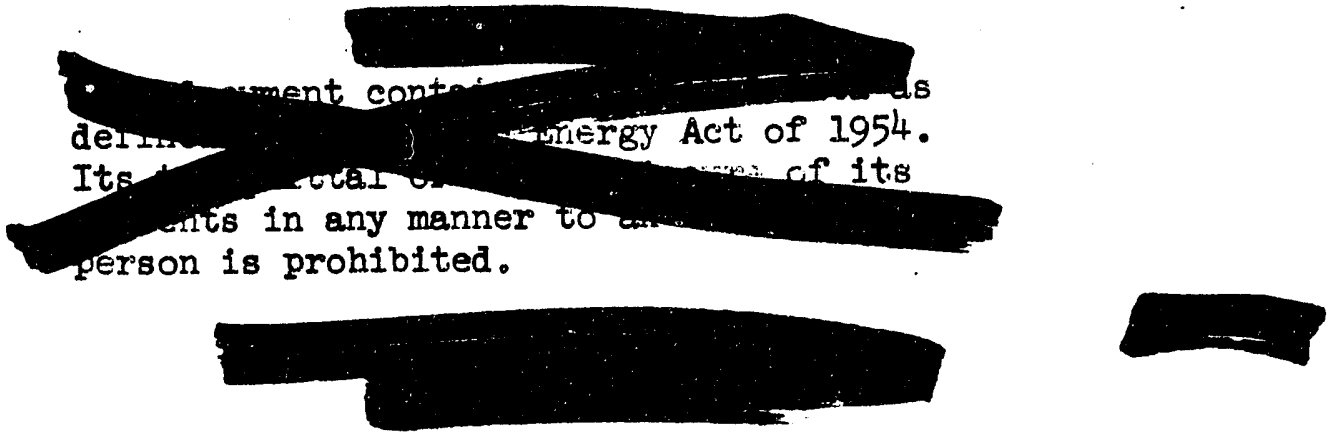
In general Pu-240 content of regular uranium discharged has been slightiy high at the older reactors and low at the $C, \mathrm{KE}$ and $\mathrm{KW}$ Reactors. For enriched uranium it has been low at all reastors, particularly the $C$ and $K$ Reactors. In order to provide a falrily unfform product that can be blended effectively at CPD we have derived and inftiated an interim goal exposure plan whlch is tabulated below:

\begin{tabular}{|c|c|c|c|c|c|}
\hline \multirow[b]{2}{*}{ Reactor } & \multirow{2}{*}{$\frac{\text { Material }}{\text { Type }}$} & \multicolumn{2}{|c|}{ Previous } & \multicolumn{2}{|c|}{ Current } \\
\hline & & P1an & Mex & Plan & Mex \\
\hline B & $\begin{array}{l}\text { Reg. } \\
\text { Enr. }\end{array}$ & $\begin{array}{l}675 \\
900\end{array}$ & $\begin{array}{r}900 \\
1600\end{array}$ & $\begin{array}{l}675 \\
900\end{array}$ & $\begin{array}{r}800 \\
1500\end{array}$ \\
\hline C & $\begin{array}{l}\text { Reg. } \\
\text { Enr. }\end{array}$ & $\begin{array}{l}640 \\
700\end{array}$ & $\begin{array}{r}900 \\
1600\end{array}$ & $\begin{array}{l}675 \\
750\end{array}$ & $\begin{array}{r}800 \\
1500\end{array}$ \\
\hline *D & $\begin{array}{l}\text { Reg. bumper } \\
\text { Inr. bumper }\end{array}$ & $\begin{array}{r}900 \\
1150\end{array}$ & $\begin{array}{l}1100 \\
1600\end{array}$ & $\begin{array}{r}900 \\
1150\end{array}$ & $\begin{array}{l}1100 \\
2500\end{array}$ \\
\hline $\mathrm{DR}$ & $\begin{array}{l}\text { Reg. } \\
\text { Ens. }\end{array}$ & $\begin{array}{l}725 \\
900\end{array}$ & $\begin{array}{r}900 \\
1600\end{array}$ & $\begin{array}{l}675 \\
900\end{array}$ & $\begin{array}{r}800 \\
1500\end{array}$ \\
\hline$F$ & $\begin{array}{l}\text { Reg. } \\
\text { Enr. }\end{array}$ & $\begin{array}{l}650 \\
850\end{array}$ & $\begin{array}{r}900 \\
1600\end{array}$ & $\begin{array}{l}675 \\
900\end{array}$ & $\begin{array}{r}800 \\
1500\end{array}$ \\
\hline H & $\begin{array}{l}\text { Enr. } \\
\text { Enr. bumper }\end{array}$ & $\begin{array}{r}900 \\
1000\end{array}$ & 1600 & $\begin{array}{r}900 \\
1000\end{array}$ & 1500 \\
\hline $\mathbf{K}$ & $\begin{array}{l}\text { Reg. } \\
\text { Bnr. }\end{array}$ & $\begin{array}{l}650 \\
650\end{array}$ & $\begin{array}{r}900 \\
1600\end{array}$ & $\begin{array}{l}675 \\
700\end{array}$ & $\begin{array}{r}900 \\
1500\end{array}$ \\
\hline
\end{tabular}

* Bumpered regular materlal w1ll be too high in Pu-240 and w1ll be diverted to the non-representative plutonium program.

It will be necessary for the Production Operation to schedule discharges that do not vary significantly from this plan. Simliarly, reactor people must use discretion in discharging material not scheduled. Where significant variations are necessary, Production scheduling should be consulted to determine what action will be required in the interests of a uniform product.

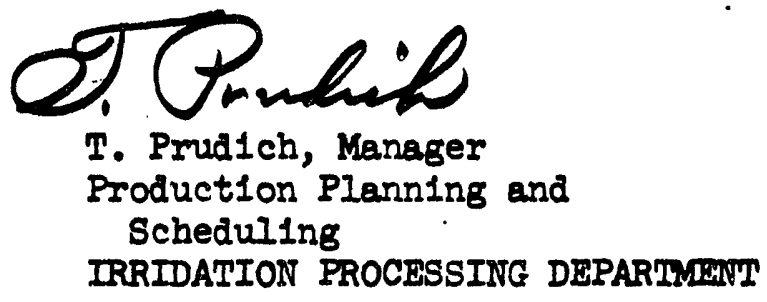

TP: ng 

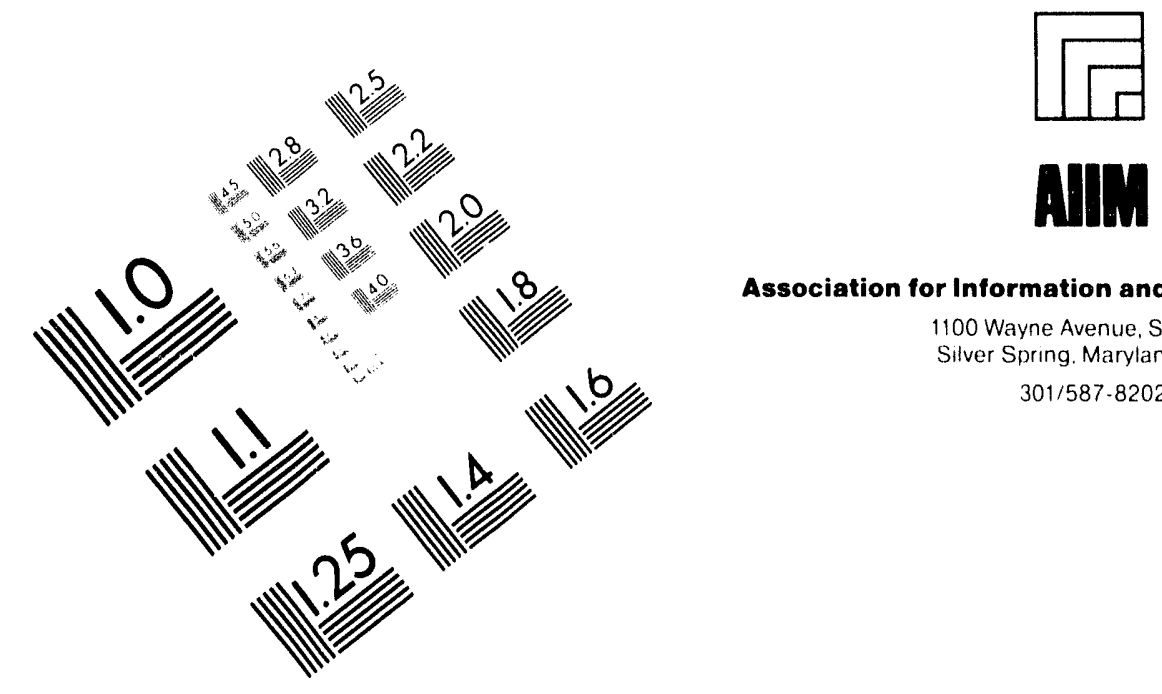

AlliM

Association for Information and Image Management

1100 Wayne Avenue, Suite 1100

Silver Spring. Maryland 20910

$301 / 587-8202$

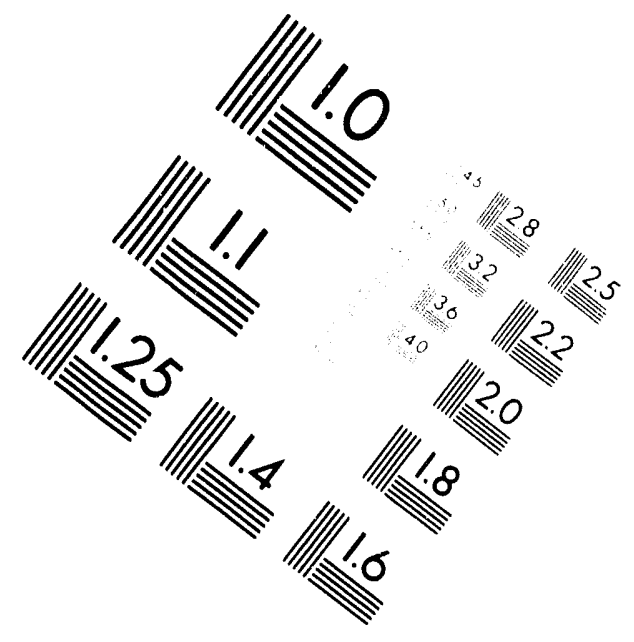

Centimeter

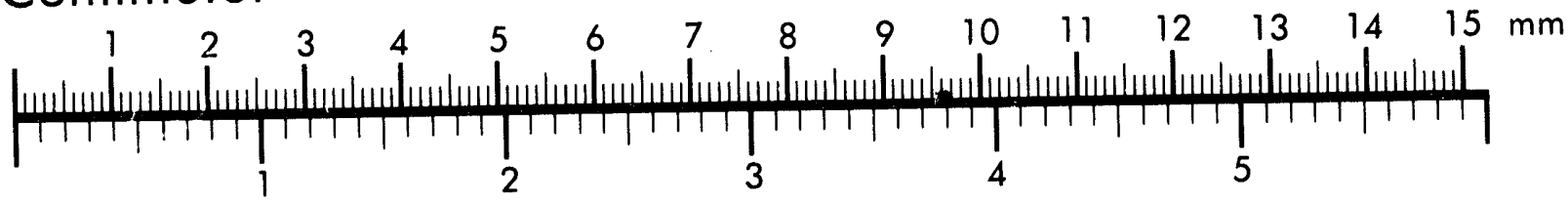

Inches
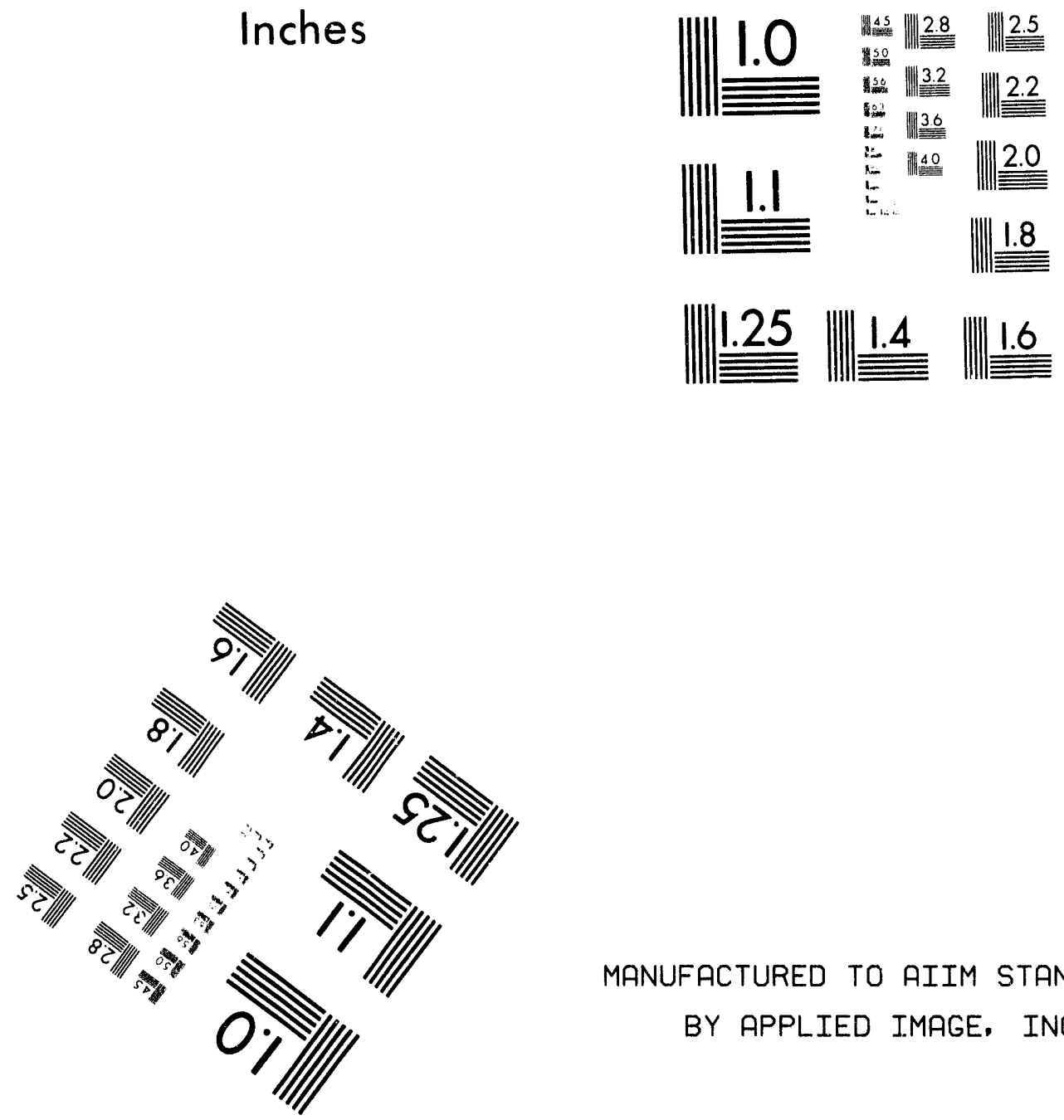

MANUFACTURED TO AIIM STANDARDS

BY APPLIED IMAGE, INC.

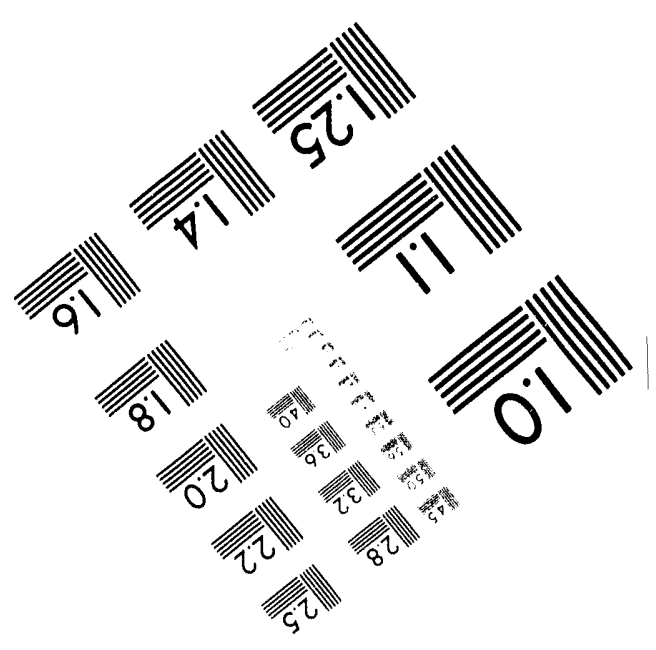




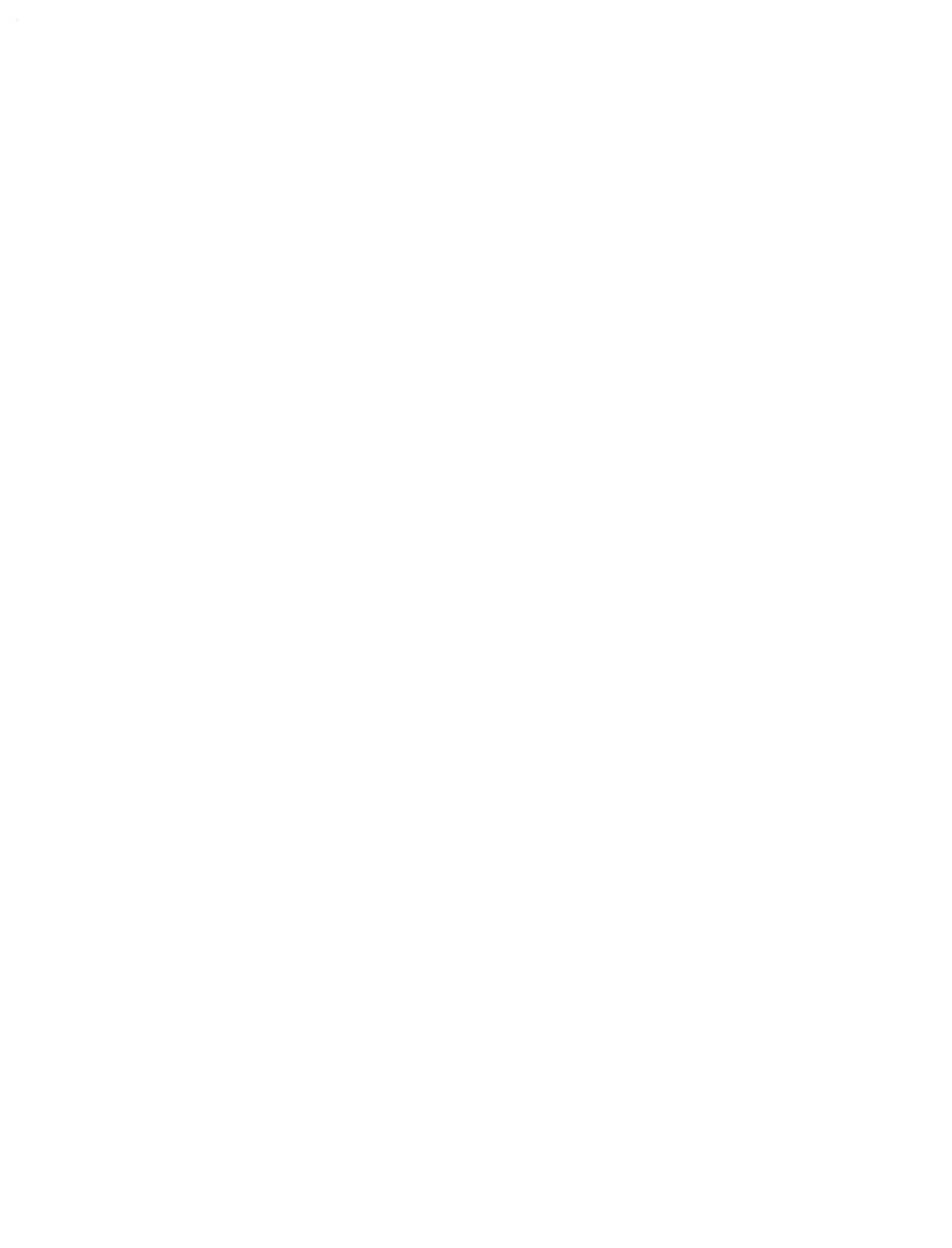



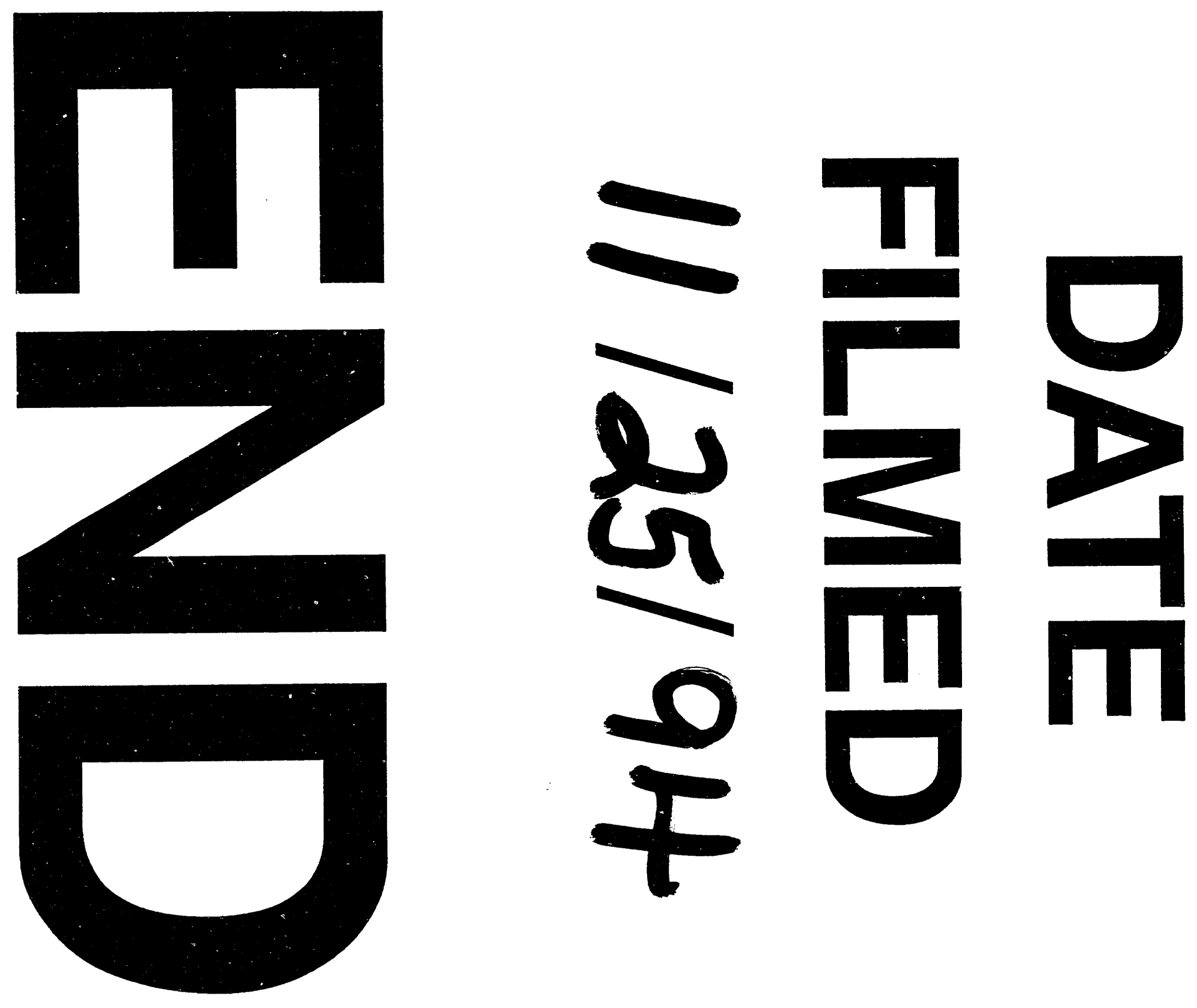